\title{
Pre- and Postsynaptic Inhibition by Opioids in Rat Striatum
}

\author{
Z. G. Jiang and R. A. North \\ Vollum Institute, Oregon Health Sciences University, Portland, Oregon 97201
}

\begin{abstract}
The physiological role of opioid peptides in the rat striatum was sought by intracellular recording in vitro. Excitatory synaptic potentials (mediated by glutamate or aspartate) and inhibitory synaptic potentials (mediated by GABA) were isolated pharmacologically and/or by positioning the stimulation electrode over the external capsule. Opioid agonists and antagonists selective for $\mu-, \delta$-, and $\kappa$-receptors were applied by superfusion. Two main actions of opioids were observed. First, $\mu$ - and $\delta$-selective opioids presynaptically inhibited the excitatory postsynaptic potential, whereas only $\delta$-selective opioids decreased the inhibitory synaptic potential. Second, a small subpopulation of cells (not medium spiny neurons) were hyperpolarized by $\delta$-selective agonists. The results indicate that the main action of opioids on striatal neurons is presynaptic inhibition of the corticostriate excitatory synaptic input.
\end{abstract}

The opioid peptides enkephalin and dynorphin are abundant within the rat neostriatum, and opioid receptors are expressed at relatively high levels. Enkephalin immunoreactivity is particularly marked in the AChE-poor patch compartment (Graybiel et al., 1981), and enkephalin coexists with GABA in a subset of medium spiny neurons, which provide a major output of the striatum to the globus pallidus (Cuello and Paxinos, 1978; Graybiel and Ragsdale, 1983). Dynorphin, on the other hand, is colocalized with GABA in the neurons that project to the substantia nigra (Anderson and Reiner, 1990). The medium spiny neurons provide recurrent collaterals (Park et al., 1980), suggesting that opioids might be involved in synaptic feedback within the striatum.

Receptors for both $\mu$ - and $\delta$-selective opioids are found in the rat striatum. $\mu$-Receptors are concentrated in striatal patches, whereas $\delta$-receptors are more diffusely distributed through patch and matrix, particularly in the ventrolateral striatum (Herkenham and Pert, 1981; Graybiel and Ragsdale, 1983; Mansour et al., 1987; see Graybiel, 1990). It is known that morphine and $\beta$-endorphin can cause stereotypic behavior and even catalepsy in rats (see Blasig, 1978), but there is little information available about opioid action at the cellular level. This lack of information is more striking in view of recent reports that enkephalin immunoreactivity is selectively reduced in the external pallidum of patients suffering from Huntington's disease (Albin et al., 1989). Opiates inhibit the firing of neurons in the striatum of the anesthetized rat (Bradley and Gayton, 1976; Nicoll et al., 1977), but with single unit recording in vivo one cannot distin-

\footnotetext{
Received May 14, 1991; revised Aug. 20, 1991; accepted Sept. 10, 1991.

This work was supported by NIH Grants DA03161 and MH40416.

Correspondence should be addressed to Dr. R. A. North at the above address.

Copyright (C) 1992 Society for Neuroscience $0270-6474 / 92 / 120356-06 \$ 05.00 / 0$
}

guish between direct actions on the cell that is recorded and actions due to changes in firing of other cells that are synaptically connected. The present experiments used intracellular recording in vitro so that presynaptic actions and direct postsynaptic actions of opioids could be differentiated.

\section{Materials and Methods}

Rats (male Sprague-Dawley) were anesthetized with halothane and killed by a heavy blow to the chest that broke major blood vessels. The brain was removed into cold $\left(1-4^{\circ} \mathrm{C}\right)$ physiological saline, and a vibratome was used to cut slices $(300 \mu \mathrm{m})$. The orientation of the slice was about $30^{\circ}$ rostral-up from the horizontal plane. A slice was completely immersed in physiological saline in the recording chamber, secured between two nylon meshes. The physiological saline flowed at $3 \mathrm{ml} / \mathrm{min}$ and was preheated so as to be at $36^{\circ} \mathrm{C}$ as it passed over the tissue. Its composition was (in mM) NaCl, 126; KCl, $2.5 ; \mathrm{NaH}_{2} \mathrm{PO}_{4}, 1.2 ; \mathrm{MgCl}_{2}$, $1.3 ; \mathrm{CaCl}_{2}, 2.4$; glucose, $10 ; \mathrm{NaH}_{2} \mathrm{CO}_{3}, 26$; saturated with $95 \% \mathrm{O}_{2}$ and $5 \% \mathrm{CO}_{2}$. Neurons were impaled with glass microelectrodes containing potassium chloride ( $2 \mathrm{M}$; resistance, $50-150 \mathrm{M} \Omega$ ). Membrane potential was recorded with an Axoclamp 2A preamplifier. Synaptic potentials were also recorded on a digital storage oscilloscope (Tektronix 2230) and an X-Y recorder (Model 200, The Recorder Co.).

Synaptic potentials were evoked by electrical stimulation using a bipolar concentric electrode (Rhodes Medical Instruments). Synaptic potentials mediated by excitatory amino acids were evoked either by placing the stimulating electrode on the corpus callosum or external capsule or by focal stimulation with bicuculline $(30 \mu \mathrm{M})$ or picrotoxin $(100 \mu \mathrm{M})$ in the superfusing solution; in both cases, the synaptic potentials were completely blocked by 6-cyano-7-nitroquinoxaline-2,3-dione (CNQX) and DL-2-aminophosphonovaleric acid (APV) (see Jiang and North, 1991). Synaptic potentials mediated only by GABA were isolated by focal stimulation, with CNQX and APV in the superfusing solution; the resulting synaptic potentials were completely blocked by bicuculline $(30 \mu \mathrm{M})$ or by picrotoxin $(100 \mu \mathrm{M})$ (Jiang and North, 1991). Synaptic potentials were usually evoked at intervals of $10 \mathrm{sec}$; potential amplitudes before and after adding drugs were measured by averaging responses to 8 or 16 stimuli.

Drugs were applied by changing the superfusing solution to one that differed only in its content of the drug. Opioid agonists used were [Met ${ }^{5}$ ]enkephalin (nonselective), DAGO (Tyr-D-Ala-Gly-MePhe-Glyol; $\mu$-receptor selective), DPDPE (Tyr-D-Pen-Gly-Phe-D-Pen; $\delta$-receptor selective), and U50488 $\cdot \mathrm{H}$ (trans-( \pm )-3,4-dichloro- $N$-methyl-[2-(1-pyrrolidinyl)cyclohexyl] benzeneacetamide methane sulfonate; $k$-receptor selective). Opioid antagonists used were naloxone (nonselective), CTAP (D-Phe-Cys-Tyr-D-Trp-Arg-Thr-Pen-Thr- $\mathrm{NH}_{2} ; \mu$-receptor selective), and ICI $174864(N, N$-bisallyl-Tyr-Aib-Aib-Phe-Leu-OH, Aib=aminoisobutyratc; $\delta$-receptor sclctive). Glutamatc and GABA were applicd either by superfusion ( $10 \mathrm{~mm}, 5-10 \mathrm{sec}$ only) or by ejecting a few nanoliters of a solution ( $10 \mathrm{~mm}$ ) from the tip of pipette positioned in the solution above the surface of the slice; a pressure pulse of $70 \mathrm{kPa}$ for $50 \mathrm{msec}$ was typically used.

\section{Results}

The results are taken from intracellular recordings from 143 principal neurons and 9 secondary cells. Principal cells have very negative resting potentials (about $-90 \mathrm{mV}$ ) and an inwardly rectifying potassium conductance; secondary cells are less polarized (about $-60 \mathrm{mV}$ ) and have a hyperpolarization- 
A
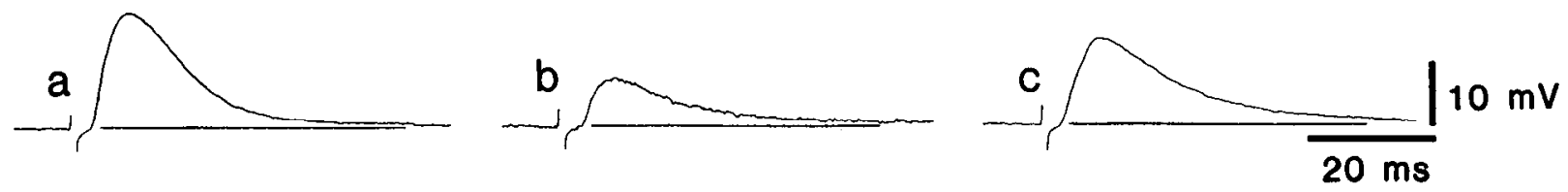

B

Control

Enk 30

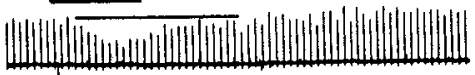

DAGO 1

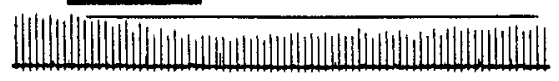

ICl 0.3

\section{Enk 30}

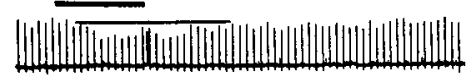

DAGO 1

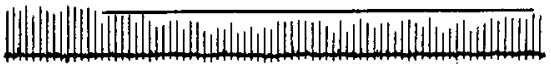

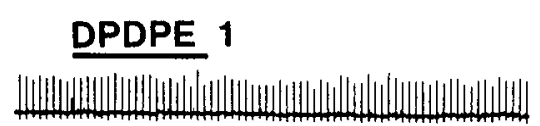

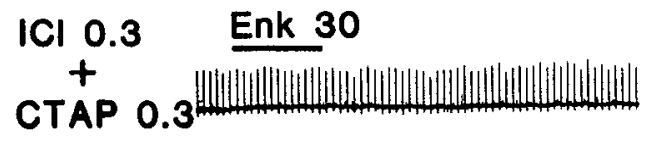

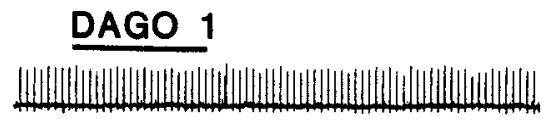

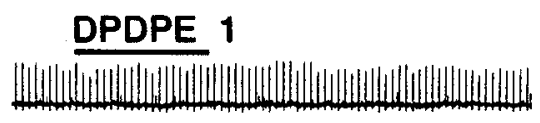

Wash
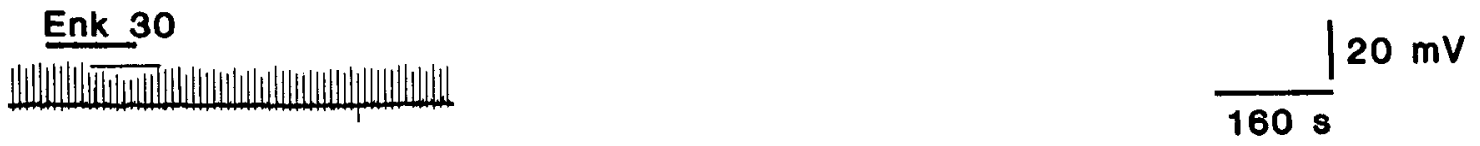

Figure 1. Inhibition of excitatory synaptic potential. Synaptic responses were evoked by stimulation of corpus callosum. $A$, [Met ${ }^{5}$ ]enkephalin inhibits synaptic potential. $a$, Control; $b$, in [Met ${ }^{5}$ enkephalin $(30 \mu \mathrm{M}) ; c$, wash. Bicuculline $(30 \mu \mathrm{M})$ was present. $B$, Both $\delta$ - and $\mu$-receptors are involved in the inhibition of glutamate-mediated synaptic potential. Different neuron from that shown in $A$. Control, Upward deflections are synaptic potentials at slow recording speed. [Met ${ }^{5}$ ]enkephalin $(E n k ; 30 \mu \mathrm{M})$, DAGO $(1 \mu \mathrm{M})$, and DPDPE $(1 \mu \mathrm{M})$ each depressed the synaptic potential. ICI 0.3 , ICI174864 (300 nM) partially blocked the effect of [Mets]enkephalin and almost fully blocked the action of DPDPE but little changed the inhibition by DAGO. ICI $0.3+C T A P$ 0.3, Further addition of CTAP $(300 \mathrm{nM})$ blocked actions of all the three opioid peptides. Wash, Enkephalin again reduced the synaptic potential after washout of the antagonist. Resting potential was $-92 \mathrm{mV}$. In this and other figures, the thick bars above the traces indicate the times during which the superfusing solution contained the agonist; the thinner lines on some figures are included to indicate the control amplitude of the synaptic potential.

activated cation conductance $\left(I_{H}\right)$ (Uchimura et al., 1990; Jiang and North, 1991). There is evidence that the principal neurons are the main projection cells (presumably medium spiny neurons) whereas the secondary neurons are interneurons (Nisenbaum et al., 1988; Wilson et al., 1990; Jiang and North, 1991). Although both types of neuron receive synaptic inputs mediated by excitatory amino acids and by GABA (Jiang and North, 1991), the effects of opioids were studied only on synaptic potentials in principal cells.

\section{Opiates reduce the synaptic potential mediated by excitatory amino acids}

[Met ${ }^{5}$ ]enkephalin reduced the amplitude of the synaptic potential in 68 of 92 cells tested (74\%) (Fig. 1, Table 1). The reduction began within $1 \mathrm{~min}$ of changing the superfusing solution to one that contained enkephalin, and reversed within 3-6 min when the enkephalin was washed from the tissue. In about one-third of cells, the synaptic potential amplitude increase above its control value for 1-3 min as the enkephalin was washed out. This action of enkephalin was seen in cells that were hyperpolarized, cells that were depolarized, and cells in which membrane potential was unaffected (see below), and there was no obvious correlation between this action and the change in resting potential.

The inhibition of the synaptic potential by enkephalin was related to the concentration applied and reached a maximum of about $40 \%$ (Fig. 2). The inhibition of the synaptic potential was also seen with selective $\mu$-receptor agonist DAGO and with the $\delta$-receptor-selective agonist DPDPE; Figures 1 and 2 show the inhibition caused by different concentrations of these agonists. When the synaptic potential was depressed by DAGO or

Table 1. A summary of the receptors through which opioids exert various actions on striatal neurons

$\begin{array}{ll}\text { Principal neurons } & \\ \text { Reduction in synaptic input } & \\ \text { Glutamate component } & \delta \text { and } \delta(\text { not } \kappa) \\ \text { GABA component } & \mu \text { (not } \mu \text { or } \kappa) \\ \text { Hyperpolarization }(17 \text { of } 93 \text { cells) } & \\ \text { Secondary neurons } & \delta \text { (not } \mu) \\ \text { Hyperpolarization (5 of } 9 \text { cells) }\end{array}$




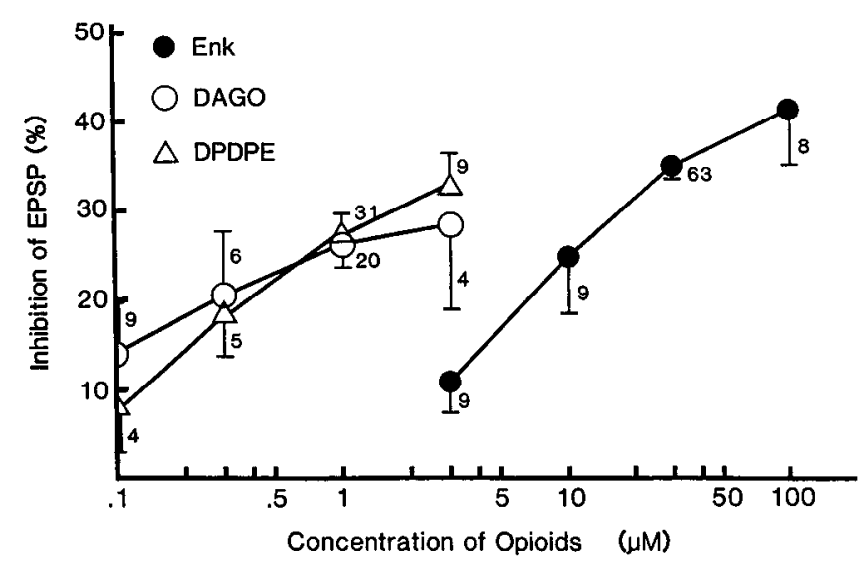

Figure 2. Inhibition of the excitatory synaptic potential caused by various concentrations of opioid agonists. Error bars are SEM, and numbers are the number of cells tested. Enk, [Met $\left.{ }^{s}\right]$ enkephalin.

DPDPE, it was also depressed by enkephalin. U50488H $(30 \mu \mathrm{M})$ had no effect on the synaptic potential $(n=6)$.

In naloxone (10-300 $\mathrm{nm})$, the concentrations of [Met ${ }^{5}$ ]enkephalin had to be greatly increased to observe a similar inhibitory effect; the dissociation equilibrium constant of naloxone was estimated to be 20 and $36 \mathrm{~nm}$ in two cells in which two to four concentrations of enkephalin were applied first in the absence and then in the presence of naloxone $(10,30$, and $300 \mathrm{~nm}$ ).

Experiments with $\mu$ - and $\delta$-selective antagonists sustained the conclusion that both $\mu$ - and $\delta$-receptors were involved in the presynaptic inhibition. ICI174864 (300 nM), a selective antagonist at $\delta$-receptors (Cotton et al., 1984), significantly reduced the inhibition caused by [Mets]enkephalin and DPDPE but did not affect the inhibition caused by DAGO (Fig. 1B). In eight cells, [Mct ${ }^{5}$ ]cnkcphalin $(30 \mu \mathrm{M})$ inhibited the synaptic potential by $31 \pm 4.0 \%$ in control conditions and by $20 \pm 2.9 \%$ in presence of ICI174864 $(p<0.05)$. Inhibition by DPDPE $(1 \mu \mathrm{M})$ was by $36 \pm 4.8 \%$ in control and by $9.2 \pm 3.1 \%$ in ICI174864 $(n=6$; $p<0.01)$. Inhibition by DAGO $(1 \mu \mathrm{M})$ was by $25 \pm 5.1 \%$ in control and by $19 \pm 2.5 \%$ in ICI1 $74864(n=6 ; p>0.05)$. CTAP (300 nM), a selective antagonist at $\mu$-receptors (Kramer et al., 1989), completely abolished the inhibition by DAGO (1 $\mu \mathrm{M})(n=2)$. When a combination of CTAP and ICI174864 was applied, the inhibition of the synaptic potential by enkephalin $(30 \mu \mathrm{M})$ was also blocked completely $(n=3)$ (Fig. 1B). A higher concentration $(1 \mu \mathrm{M})$ of CTAP reduced the synaptic potential by $10-25 \%$ of the control.
Glutamate microejection (10 mM, $70 \mathrm{kPa}, 10-100 \mathrm{msec}$ ) produced a depolarization of 5-20 mV in amplitude and 5-10 sec in duration. Enkephalin $(10-100 \mu \mathrm{M})$ did not alter this depolarization whether $(n=3)$ or not $(n=5) \operatorname{TTX}(1 \mu \mathrm{M})$ was present (see Fig. 4A).

\section{Opiates reduce the synaptic potential mediated by GABA}

[Met ${ }^{s}$ ]enkephalin $(30 \mu \mathrm{M})$ reduced the synaptic potential by 30 $\pm 7.8 \%$ in six cells (Fig. 3 ) and had no effect in four. DPDPE $(1 \mu \mathrm{M})$ depressed the synaptic potential in all five cells tested (by $28 \pm 7.2 \%$ ) (Table 1). DAGO $(1 \mu \mathrm{M} ; n=5)$ and U50488H (30 $\mu \mathrm{M} ; n=3)$ had no effect. ICI174864 (300 nм) completely abolished the inhibitory action of enkephalin $(n=5)$ and DPDPE $(n=3)$ (Fig. 3), but CTAP (300 nM) had no effect $(n=3)$.

Brief application of GABA by superfusion (10 mM, 5-10 sec) depolarized cells by $8-25 \mathrm{mV}$ for 20-60 sec. Enkephalin (10$100 \mu \mathrm{M})$ did not alter this depolarization $(n=4)$ (Fig. $4 B$ ).

\section{Opioids hyperpolarize a subset of neurons}

Most secondary cells were hyperpolarized by enkephalin (30 $\mu \mathrm{M} ; 5$ of 9 cells) (Table 1). Although the effect was small (2.6 \pm $0.68 \mathrm{mV}$ ), it was quite reproducible on a given cell and was sufficient to block completely the firing of action potentials (Fig. $5 B)$. Secondary cells were also hyperpolarized by DPDPE $(0.3-$ $1 \mu \mathrm{M} ; n=3)$ but not by DAGO $(1 \mu \mathrm{M} ; n=6)$.

Eighteen percent of principal cells $(n=93)$ were hyperpolarized by $3.8 \pm 0.34 \mathrm{mV}(n=17)$ (Figs. $4 A, 5 B$; Table 1); eight cells were depolarized by $2.1 \pm 0.22 \mathrm{mV}$ (Table 1). The hyperpolarization was accompanied by a small decrease in input resistance $(14 \pm 1.1 \% ; n=17)$. The hyperpolarization usually became less when enkephalin was applied repeatedly to the same cell; it was not affected by TTX ( $1 \mu \mathrm{M} ; n=3)$. DAGO ( 0.3 and $1 \mu \mathrm{M} ; n=4)$ also hyperpolarized principal cells, but DPDPE (1 $\mu \mathrm{M} ; n=5$ ) had no effect (Fig. 5A). Hyperpolarizations were completely blocked by naloxone $(1 \mu \mathrm{M} ; n=6)$.

\section{Discussion}

Opiate actions on extrinsic synaptic inputs to the striatum Striatal neurons receive excitatory synaptic inputs from a number of sources. A predominate input is from all regions of the cerebral cortex (Glees, 1944; Gerfen, 1984; McGeorge and Faull, 1989), and the transmitter is a glutamate-like excitatory amino acid (Spencer, 1976; Cordingley and Weight, 1986; Malenka and Kocsis, 1988). The reduction by opioids of the synaptic potential is interpreted as an inhibition of release of excitatory amino acid from corticostriate fibers (hereafter referred to as
Figure 3. $\delta$-Receptor is involved in inhibition of GABA-mediated synaptic potential. Synaptic potential was induced by stimulation $0.2 \mathrm{~mm}$ from the recording site; CNQX $(10 \mu \mathrm{M})$ and APV $(30 \mu \mathrm{M})$ were present. Upper row, [Met ${ }^{5}$ ]enkephalin $(E n k, 30 \mu \mathrm{M})$ and DPDPE $(1 \mu \mathrm{M})$, but not DAGO $(1 \mu \mathrm{M})$, reduced the synaptic potential. Lower row, The reduction was blocked by ICI174864 $(0.3 \mu \mathrm{M})$. Resting potential was $-90 \mathrm{mV}$.
Enk 30

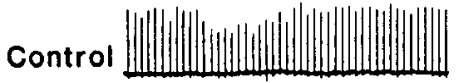

DAGO 1

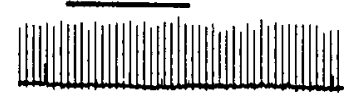

Enk 30

ICl 0.3

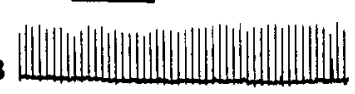

DAGO 1

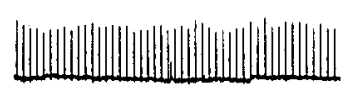

DPDPE 1

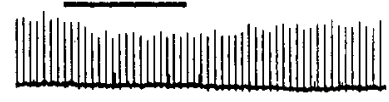




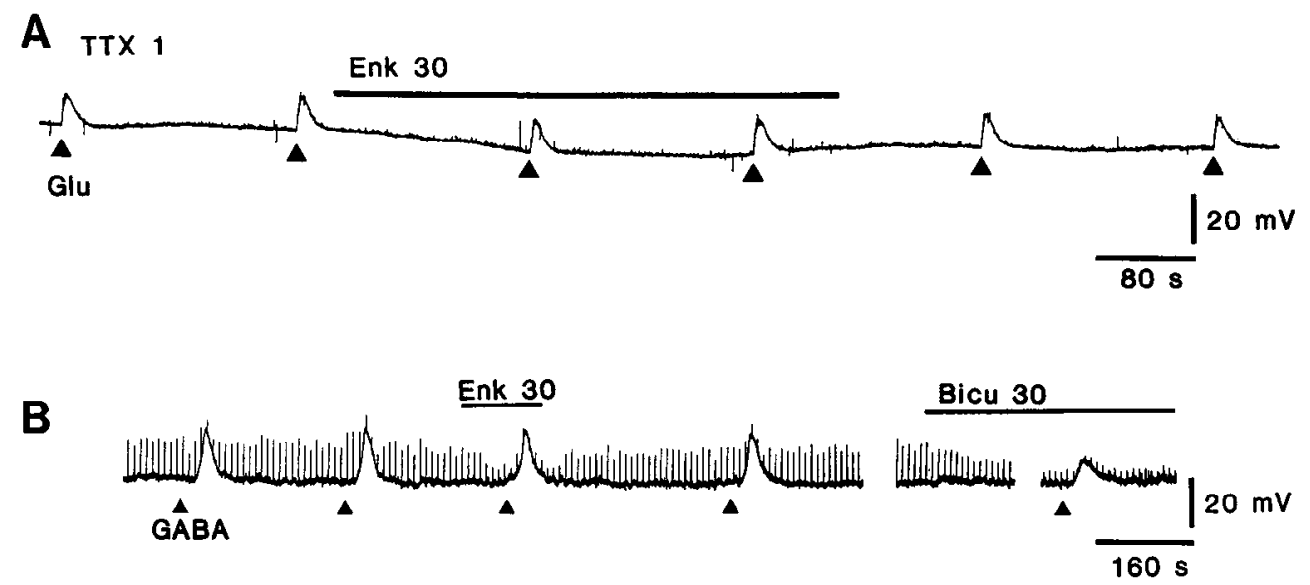

Figure 4. Depolarizations caused by exogenous glutamate $(G l u)$ and GABA are unaffected by opioids. $A$, Glutamate was applied by pressure pulse (triangles; $70 \mathrm{kPa}, 50 \mathrm{msec}$ ). The depolarizations were unaffected by [Met $\mathrm{M}^{5}$ ]enkephalin $(30 \mu \mathrm{M})$. TTX $(1 \mu \mathrm{M})$ was present throughout. Note the hyperpolarization of this cell by [Met ${ }^{5}$ ]enkephalin. Resting potential, $-88 \mathrm{mV}$. B, GABA was applied by superfusion to a different cell (triangles; $10 \mathrm{~mm}, 7 \mathrm{sec}$ ). The depolarizations caused by GABA were not changed by [Met ${ }^{5}$ ]enkephalin. Brief upward deflections are synaptic potential evoked by focal stimulation in presence of CNQX and APV; these were depressed by [Met ${ }^{5}$ ]enkephalin (Enk; $\left.30 \mu \mathrm{M}\right)$. Later, bicuculline (Bicu; $\left.30 \mu \mathrm{M}\right)$ almost completely blocked the synaptic potential and much reduced the depolarization caused by exogenous GABA. Resting potential, $-89 \mathrm{mV}$.

glutamate) because opioids did not reduce the depolarization caused by direct application of glutamate.

Some other agonists (muscarine: Sugita et al., 1991; baclofen: Seabrook et al., 1990; Uchimura and North, 1991; carbachol: Malenka and Kocsis, 1988; adenosine: Malenka and Kocsis, 1988; Uchimura and North, 1991) also inhibit the release of glutamate measured electrophysioiogically. However, the maximal inhibition of synaptic potential by opioids was only $40 \%$, whereas the other agonists cause close to $100 \%$ inhibition. It is possible that all presynaptic fibers express opioid receptors but these couple only weakly to inhibition of glutamate release, although complete inhibition of release can be observed where opioids inhibit transmitter release from peripheral neurons (North and Williams, 1983). Another possibility is that the synaptic potential results from glutamate release from two sets of presynaptic fibers that are both excited under the present ex- perimental conditions; release from one set might be completely inhibited and release from the others unaffected.

Both $\mu$ - and $\delta$-receptors appear to be present on the glutamatecontaining fibers, although one cannot determine if they are on the same or different fibers on the basis of the present results. Autoradiographic studies show that $\mu$-receptors are most dense in patches of the striatum, whereas $\delta$-receptors are more uniformly distributed (Herkenham and Pert, 1981; Mansour et al., 1987; Tempel and Zukin, 1987). We do not know if any given cell in the present study was located in the patch or matrix; however, Kawaguchi et al. (1989) did not find any obvious electrophysiological differences between the cells in the two compartments.

Extracellular recording in vivo has shown that opioids inhibit the firing of striatal neurons; in those experiments the cells must be induced to fire by application of an excitatory amino acid
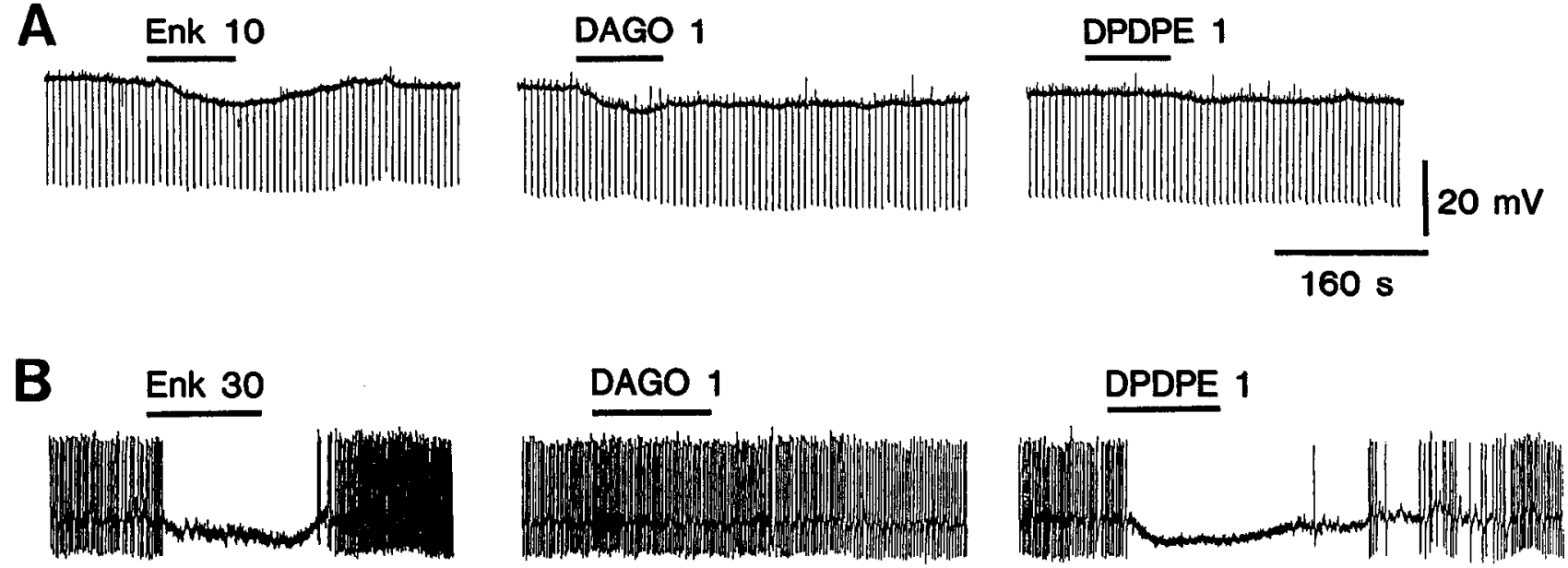

Figure 5. Principal cells are hyperpolarized by $\mu$-receptor agonists and secondary cells are hyperpolarized by $\delta$-receptor agonists. $A$, A principal cell was hyperpolarized by [Met ${ }^{3}$ ]enkephalin $(E n k ; 10 \mu \mathrm{M})$ and by DAGO $(1 \mu \mathrm{M})$ but not by DPDPE $(1 \mu \mathrm{M})$. Downward deflections are electrotonic potentials evoked by current pulses of $500 \mathrm{pA}$ for $80 \mathrm{msec}$. Resting potential, $-85 \mathrm{mV} . B$, A spontaneously firing secondary cell was hyperpolarized by [Met ${ }^{\text {s] }}$ enkephalin $(30 \mu \mathrm{M})$ and DPDPE $(1 \mu \mathrm{M})$ but not by DAGO $(1 \mu \mathrm{M})$. Calibrations apply to $A$ and $B$. 
(Fry and Zieglgänsberger, 1979; Hakan and Henriksen, 1989). The depolarization of the applied excitatory amino acid would presumably sum with ongoing excitatory synaptic input to bring the cell to threshold; the presynaptic inhibition of that input observed in the present study could thus be responsible for the inhibition of firing seen in vivo.

\section{Opioid actions on GABA release within the striatum}

The GABA-mediated synaptic potential results from stimulation of local cells or terminals, most probably collaterals of the medium spiny neurons themselves (see Jiang and North, 1991). This was selectively reduced by activation of $\delta$-reccptors. Inhibition of GABA release by opioids has also been shown by neurochemical measurements on slices of rat globus pallidus (Dewar et al., 1987), where much of the GABA would be expected to be in terminals of striatal neurons; in those studies inhibition was observed with a nonselective agonist (DADLE, Tyr-D-Ala-Gly-Phe-D-Leu) but not with a $\mu$-selective agonist (FK33824, Tyr-D-Ala-Gly-MePhe-Met $(O)$-ol) or ethylketazocine, a result consistent with involvement of $\delta$-receptors.

Inhibition of GABA-mediated synaptic potentials by opioids is seen in several other areas of the brain (see North, 1991). In the hippocampus (Nicoll et al., 1980), the GABA-releasing terminals are provided by local interneurons; these neurons also express opioid receptors, activation of which results in membrane hyperpolarization (Madison and Nicoll, 1988). In the case of the striatum, the GABA component of the synaptic potential arises largely from collateral branches of the medium spiny neurons themselves; this implies that the cell bodies might also express $\delta$-receptors. However, only a small proportion of the principal cells were hyperpolarized, and this involved $\mu$-rather than $\delta$-receptors. Opioids inhibit voltage-dependent calcium currents in several tissues (see North, 1991), and this provides another mechanism by which $\delta$-receptor activation might inhibit GABA release. Consistent with this, we found in preliminary studies that DPDPE ( $1 \mu \mathrm{M} ; 7$ of 10 cells) and DAGO $(1 \mu \mathrm{M} ; 3$ of 8 cells) reduced the amplitude and duration of the calcium action potential, recorded in TTX $(1 \mu \mathrm{M})$, and barium (1 mM) or tetraethylammonium (20 mM).

\section{Direct actions of opioids on striatal neurons}

About $50 \%$ of secondary cells were hyperpolarized by DPDPE but not by DAGO, suggesting that at least a subset of secondary cells express $\delta$-receptors. Although conclusions rcgarding the secondary cells are suspect because of the small sample, the hyperpolarization was reproducible and sufficient to inhibit spontaneous firing (Fig. 5). This result is of interest in light of the proposal that these cells are striatal interneurons, which would include cholinergic neurons. Opioids inhibit the release of ACh from striatal tissue, and this is thought to involve the $\delta$-receptor (Mulder et al., 1984; but see Lapchak et al., 1989). This raises the possibility that some secondary cells expressing $\delta$-receptors are the large cholinergic aspiny cells. Intracellular recording from neurochemically identified cells will be needed to resolve this important question, but this will be difficult in view of the low abundance of the cholinergic neurons (see Wilson et al., 1990).

\section{References}

Albin RL, Young AB, Penney JB (1989) The functional anatomy of basal ganglia disorders. Trends Neurosci 12:366-375.

Anderson KD, Reiner A (1990) Extensive co-occurrence of substance
$P$ and dynorphin in striatal projection neurons: an evolutionarily conserved feature of basal ganglia organization. J Comp Neurol 295: 339-369.

Blasig J (1978) On the role of brain catecholamines in acute and chronic opiate action. In: Developments in opiate research (Herz A, ed), pp 279-356. New York: Dekker.

Bradley PB, Gayton RJ (1976) Action and interactions of morphine and dopamine on single neurones in the rat caudate nucleus. $\mathrm{Br} \mathbf{J}$ Pharmacol 57:425-426.

Cordingley GE, Weight FF (1986) Non-cholinergic synaptic excitation in neostriatum: pharmacological evidence for mediation by a glutamate-like transmitter. Br J Pharmacol 88:847-856.

Cotton R, Giles MG, Miller L, Shaw JS, Timms D (1984) ICI174864: a highly selective antagonist for the delta opioid receptor. Eur J Pharmacol 97:331-332.

Cuello AC, Paxinos G (1978) Evidence for a long leu-enkephalin striopallidal pathway in rat brain. Nature 271:178-180.

Dewar D, Jenner P, Marsden CD (1987) Effects of opioid agonist drugs on the in vitro release of ${ }^{3} \mathrm{H}-\mathrm{GABA},{ }^{3} \mathrm{H}$-dopamine and ${ }^{3} \mathrm{H}-5 \mathrm{HT}$ from slices of rat globus pallidus. Biochem Pharmacol 36:1738-1741.

Fry JP, Zieglgänsberger W (1979) Comparison of the effects of GABA and enkephalin on synaptically evoked activity in the rat striatum. Appl Neurophysiol 42:54-56.

Gerfen CR (1984) The neostriatal mosaic: compartmentalization of corticostriatal input and striatonigral output systems. Nature 311 : $461-464$.

Glees P (1944) The anatomical basis of corticostriate projections. J Anat 78:47-51.

Graybiel AM (1990) Neurotransmitters and neuromodulators in the basal ganglia. Trends Neurosci 13:244-254.

Graybiel AM, Ragsdale CW (1983) Biochemical anatomy of the striatum. In: Chemical neuroanatomy (Emson PC, ed), pp 427-504. New York: Raven.

Graybiel AM, Ragsdale CW, Yoneoka ES, Elde RP (1981) An immunohistochemical study of enkephalins and other neuropeptides in the striatum of the cat with evidence that the opiate peptides are arranged to form mosaic pallerns in register with the striosomal compartments visible by acetylcholinesterase staining. Neuroscience 6: 377-397.

Hakan KL, Henriksen SJ (1989) Opiate influences on nucleus accumbens neuronal electrophysiology: dopamine and non-dopamine mechanisms. J Neurosci 9:3538-3546.

Herkenham M, Pert CB (1981) Mosaic distribution of opiate receptors, parafasicular projections and acetylcholinesterase in rat striatum. $\mathrm{Na}$ ture 291:415-418.

Jiang Z-G, North RA (1991) Membrane properties and synaptic responses of two types of rat striatal neurones in vitro. J Physiol (Lond) 443:533-553.

Kawaguchi Y, Wilson CJ, Emson PC (1989) Intracellular recording of identified neostriatal patch and matrix spiny cells in a slice preparation preserving cortical inputs. J Neurophysiol 62:1052-1068.

Kramer TH, Shook JE, Kazmierski W, Ayres EA, Wire WS, Hruby VJ, Burks TF (1989) Novel peptidic mu opioid antagonists: pharmacologic characterization in vitro and in vivo. J Pharmacol Exp Ther 249:544-551.

Lapchak PA, Araujo DM, Collier B (1989) Regulation of endogenous acetylcholine release from mammalian brain slices by opiate receptors: hippocampus, striatum and cerebral cortex of guinea pig and rat. Neuroscience 31:313-325.

Madison DV, Nicoll RA (1988) Enkephalin hyperpolarizes interneurones in the rat hippocampus. J Physiol (Lond) 398:123-130.

Malenka RC, Kocsis JD (1988) Presynaptic actions of carbachol and adenosine on corticostriatal synaptic transmission studied in vitro. $\mathrm{J}$ Neurosci 8:3750-3756.

Mansour A, Khachaturian H, Lewis ME, Akil H, Watson SJ (1987) Autoradiographic differentiation of mu, delta, and kappa opioid receptors in the rat forebrain and midbrain. J Neurosci 7:2445-2464.

McGeorge AJ, Faull RLM (1989) The organization of the projection from the cerebral cortex to the striatum in the rat. Neuroscience 29: 503-537.

Mulder AH, Wardeh G, Hogenboom F, Frankhuyzen AL (1984) Kappa and delta opioid receptor agonists differentially inhibit striatal dopamine and acetylcholine release. Nature 308:278-280.

Nicoll RA, Siggins GR, Ling N, Bloom FE, Guillemin R (1977) Neuronal actions of endorphin and enkephalins among brain regions: a 
comparative microiontophoretic study. Proc Natl Acad Sci USA 74: 2548-2552.

Nicoll RA, Alger BE, Jahr CE (1980) Enkephalin blocks inhibitory pathways in the vertebrate CNS. Nature 287:22-25.

Nisenbaum ES, Orr WB, Berger TW (1988) Evidence for two functionally distinct subpopulations of neurons within the rat striatum. $J$ Neurosci 8:4138-4150.

North RA (1991) Opioid actions on membrane ion channels. In: Handbook of experimental pharmacology (Herz A, Akil H, Simon EJ, eds), in press. Berlin: Springer.

North RA, Williams JT (1983) How do opiates inhibit transmitter release. Trends Neurosci 6:337-339.

Park MR, Lighthall JW, Kita ST (1980) Medium spiny neuron projection from the rat striatum: an intracellular horseradish peroxidase study. Brain Res 194:359-369.

Seabrook GR, Howson W, Lacey MG (1990) Electrophysiological characterisation of potent agonists and antagonists at pre- and postsynaptic $\mathrm{GABA}_{\mathrm{B}}$ receptors on neurones in rat brain slices. Br J Pharmacol 101:949-957.

Spencer HJ (1976) Antagonism of cortical excitation of striatal neu- rons by glutamic acid diethylester: evidence for glutamic acid as an excitatory transmitter in the rat striatum. Brain Res 102:91-101.

Sugita S, Uchimura N, Jiang Z-G, North RA (1991) Distinct muscarinic receptors inhibit release of excitatory amino acids and $\gamma$-aminobutyric acid in mammalian brain. Proc Natl Acad Sci USA 88:2608-2611.

Tempel A, Zukin RS (1987) Neuroanatomical patterns of the mu, delta and kappa opioid receptors of rat brain as determined by quanlitative in vitro autoradiography. Proc Natl Acad Sci USA 84:43084312.

Uchimura N, North RA (1991) Baclofen and adenosine inhibit $\gamma$-aminobutyric acid and glutamate release in rat nucleus accumbens. $J$ Pharmacol Exp Ther 258:663-668.

Uchimura N, Cherubini E, North RA (1990) Cation current activated by hyperpolarization $\left(I_{H}\right)$ in a subset of rat nucleus accumbens neurons. J Neurophysiol 64:1847-1850.

Wilson CJ, Chang HT, Kitai ST (1990) Firing patterns and synaptic potentials of identified giant aspiny interneurons in the rat neostriatum. J Neurosci 10:508-519. 